\title{
THE TABOR AND NORTHERN RAILROAD
}

\author{
By Otha D. Wearin \\ Nishna Vale Farm, Hastings, Iowa
}

The establishment of the Tabor and Northern Railroad, the world's shortest standard guage line ( 8.79 miles) between Tabor, Iowa, in Fremont County and Malvern, Iowa, in Mills County, was inspired by an effort to relocate Tabor College.

In 1889, the college was issued an invitation to move to Red Oak, Iowa, where rail facilities were available. The possibility of losing its institution of higher learning sparked a surge of local pride that launched the building of the rail line to connect the inland Tabor with the main line of the Chicago, Burlington, and Quincy at Malvern. The college was the prime mover in the venture. Forty-three thousand dollars worth of bonds were sold. Professor Thomas McClelland was elected President of the new company and served in that capacity until his resignation in 1891. The first engine to cross the Mississippi River at Burlington, Iowa, on the C. B. \& Q. was purchased by the college and leased to the new railroad. The system boasted of a passenger coach and some additional rolling stock.

In 1898, the trustees decided that the business of running a college should not include running a railroad. In the following year Robert McClelland of Omaha, Neb., one of the trustees, purchased the bonds from the college, moved to Tabor and took over the "shortline." Active management was assumed by his son Robert and his daughter Myra McClelland.

The "short line" was given an elaborate send off in the Tabor College Annual, "The Cardinal," for 1899. The advertisement read as follows: 


\section{TABOR AND NORTHERN RAILWAY SYSTEM}

\section{General Offices, Tabor, Iowa}

The $\mathrm{T}$ and $\mathrm{N}$ is not as long as the "Q" (Chicago, Burlington, and Quincy) but it is just as wide. It is as wide in several ways. It is as wide awake, its doors are as wide and we'd just as soon "wide" on it.

Robert McClelland - President and Manager

Thos. McClelland - Vice-President

H. C. Dye - Secretary and Treasurer

Charles R. Wilson - Traffic Manager

H. M. Hamlin - Supt. and Auditor

There was no mention of the fact that the system was less than nine miles long.

The train made two round trips daily between Tabor and Malvern, making connections with the C. B. \& Q. and the Wabash. Operation was comparatively simple since only one train plied the route. Signal systems were unnecessary. The crew was composed of Tabor residents and extended accommodations to patrons far beyond the normal call of duty. It was not uncommon for the train to make an unscheduled stop at a road crossing or near a farmstead to pick up a passenger or to unload some special freight. The Tabor Beacon, in its Centennial Edition of July 23, 1952, quotes Joe Lybarger, the system's last engineer, as saying:

“For ten years straight I didn't have a vacation. We were running twice a day. During the last three years we operated once a day and sometimes only twice a week. We had as many as 20 car loads of cattle and hogs go out of here in a day's time and there was one day when there were 28 cars." 
The demand for passenger service began to decline even before the coming of the paved road. The ancient coach was abandoned in 1919, during my attendance at Tabor College Academy. The few passengers who patronized the line, including myself, were provided with boxes and barrels as seats in the freight car. A pot-bellied coal stove supplied heat in cold weather, after a fashion. Riding that little line that rolled and rocked through Mills County under such circumstances proved to be somewhat of a feat in gymnastics.

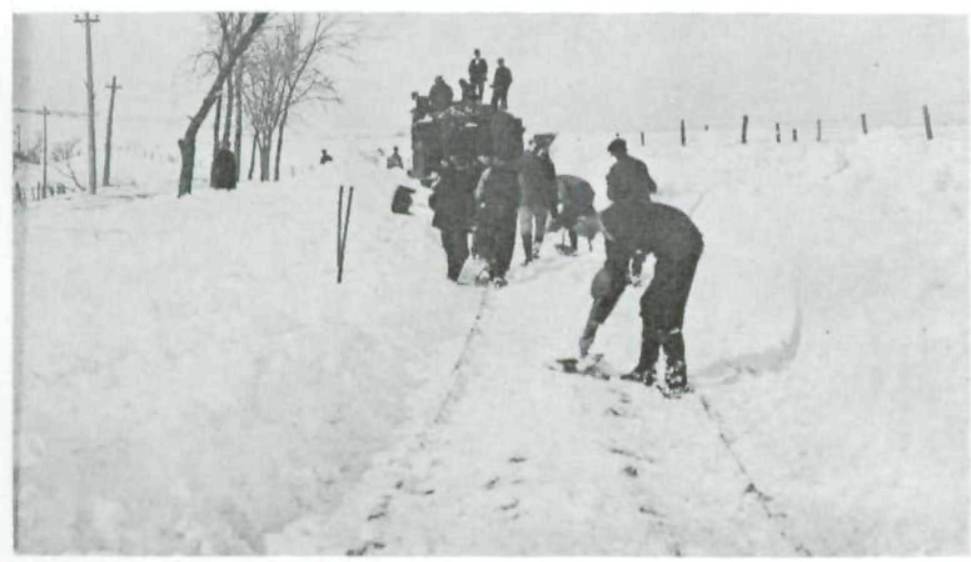

Farmers Along the Route of the Tabor and Northern Assist in Digging Out the Snowbound Train

The Tabor and Northern paid some substantial profits in the early days of operation. During the last decade of its service a motor bus was pressed into service over the rails, but the end of its career was near at hand. 
The Council Bluffs Nonpareil reported the final chapter on Oct. 10, 1934:

“The world's shortest railroad, mechanical slave to residents of the area since 1890, went on the auction block Wednesday and when the hammer said 'sold,' the Tabor and Northern was the property of the Burlington Route. The trackage, the decrepit locomotive, two gas cars, plus miscellaneous rolling stock, bridges, culverts, and other items needed in the operation of a railroad, were included in the price of $\$ 5,000$, plus $\$ 2,735.85$ in back taxes. The bidder, J. C. Pryor, attorney for the Burlington, announced after the sale that the system would be junked. It was as if the conductor had called for the last time 'Everybody out. This is the end of the line." "

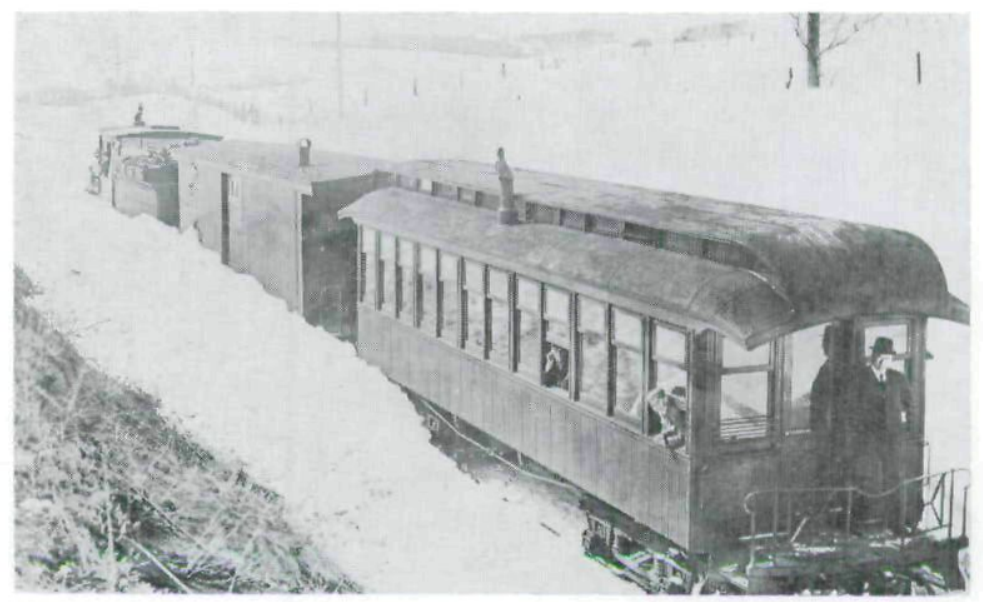

SNOWbOund TABor and Northern

A HIGHLy FAVORED PEOPLE, mindful of their dependence on the bounty of Divine Providence should seek fitting occasion to testify gratitude and ascribe praise to Him who is the author of their many blessings. It behooves us then to look back with thankful hearts over the past year and bless God for his infinite mercy in vouchsafing to our people, freedom from pestilence and famine, to our husbandmen abundant harvests, and to them that labor, a recompense of their toil.

President Harrison, Thanksgiving Proclamation 
Copyright of Annals of Iowa is the property of State of Iowa, by \& through the State Historical Society of Iowa and its content may not be copied or emailed to multiple sites or posted to a listserv without the copyright holder's express written permission. However, users may print, download, or email articles for individual use. 